\title{
NEW UPDATED CLASSIFICATION AND TREATMENT MODALITY FOR ORAL SUBMUCOUS FIBROSIS: A REVIEW
}

\author{
Dr.Lajri Bagde ${ }^{1}$, Dr.Ashish Lanjekar ${ }^{2}$, Dr. Ramhari Sathawane ${ }^{3}$, Dr. Rakhi Chandak ${ }^{4}$, Dr. Romita Gaikwad ${ }^{5}$, \\ Dr. Kshitija Bhakte ${ }^{1}$
}

1- Postgraduate Student, 2- Reader and Guide, 3- Professor and HOD, 4-Reader, 5-Sr lecturer, Department Of Oral Medicine and Radiology, Swargiya Dadasaheb Kalmegh Smruti Dental College and Hospital, Nagpur

\section{ABSTRACT}

Oral submucous fibrosis (OSMF) is a premalignant condition mainly associated with the practice of chewing betel quid containing areca nut, a habit common among South Asian people. Data from recent epidemiological studies provide overwhelming evidence that areca nut is the main etiological factor for OSMF. Over the years, many classification systems have been documented in medical literature based on clinical, histopathological, or functional aspects. Each classification has its own merits and demerits. An attempt is made to provide and update the knowledge of classification system of OSMF so that it can assist the clinicians, be beneficial in researches and academics in categorizing this potentially malignant disease for early detection, prompt management, and reducing the mortality.

KEYWORDS: Update classification, Blanching, Collagen, Fibrosis, Oral Submucous Fibrosis

\section{INTRODUCTION}

Oral submucous fibrosis is a potentially malignant disease that is insidious and chronic in nature affecting the entire oral cavity, sometimes extending to the pharynx. It has drawn considerable attention in recent past due to its high malignant potential and chronic debilitating and resistant nature. It is seen predominantly in people of Asian descent especially among Indians ${ }^{1}$. Sushrutha in 600 B. C described a condition similar to OSMF as "Vidari" ${ }^{2}$.OSMF was first described in the modern literature by Schwartz in 1952 who coined the term "atrophicaidiopathica mucosae oris" to describe an oral fibrosing disease, who discovered it in 5 Indian women in Kenya. ${ }^{3}$ Joshi subsequently coined the term "OSMF" for the condition in $1953 .{ }^{4}$

The aetiology, once thought to be idiopathic, is now confirmed to be multifactorial in origin with possible etiological factors been capsaicin in chillies, deficiencies in iron, zinc and essential vitamins. $^{5-8}$

\section{ETIOLOGY}

\section{ARECA ALKALOIDS CAUSING FIBROBLAST PROLIFERATION}

Areca nut (betel nut) chewing is one of the most common causes of OMSF which contains tannins $(11 \%-12 \%)$ and alkaloids such as arecoline, arecadine, guvacoline, guvacine. Out of all these arecoline is the main agent responsible for fibroblast proliferation. Under the influence of slaked lime $(\mathrm{Ca}(\mathrm{OH}) 2)$, arecoline get hydrolyzed to arecadine, which has pronounced effects on fibroblasts. ${ }^{9}$ A study by Harvey et al showed that exposures to $0.1-10 \mu \mathrm{g} / \mathrm{ml}$ arecoline stimulates fibroblasts and concentrations more than $25 \mu \mathrm{g} / \mathrm{ml}$, inhibits fibroblast growth and collagen synthesis. ${ }^{10}$ 


\section{CLONAL SELECTION OF OSMF FIBROBLASTS BY ARECOLINE}

Studies have shown that arecoline causes elevated collagen synthesis by OSMF fibroblasts compared to normal fibroblast. This could reflect clonal selection of a cell population in altered tissues under the influence of local factors such as IL-1 from inflammatory cells ${ }^{11}$.

\section{HIGH COPPER CONTENT IN ARECA NUT AND FIBROSIS}

The average daily intake of copper by adults from diet in developing countries is between 0.6 and 1.6 $\mathrm{mg} /$ day. An adult Indian chewing areca nut daily consumes over $5 \mathrm{mg}$ of copper/day. ${ }^{12}$ Studies done to evaluate serum and tissue copper levels in OSMF patients showed raised tissue copper levels in buccal mucosal biopsies of OSMF patients. The tissue copper levels measured by mass absorption spectrometry showed that the tissue copper levels in OSMF patients were $5.5 \mu \mathrm{g} / \mathrm{gm}$ compared to $4 \mu \mathrm{g} /$ $\mathrm{gm}$ in non areca nut chewers. Also the concentration gradient of copper was noted in lining mucosa with higher content of copper in epithelium compared to deeper connective tissues and muscle layers. ${ }^{13}$

\section{GENETICS AND IMMUNOLOGY}

A genetic component is believed to be involvement in OSMF because there are cases reported in medical literature in people without any history of betel nut chewing or chilli ingestion. Patients with OSMF have increased frequency of HLA-A10, HLA-B7, and HLA-DR3. ${ }^{14}$ The increase in CD4 cells and cells with HLA-DR in these diseased tissues shows activation of most lymphocytes and increased number of Langerhans cells. These immunocompetent cells and high value of CD4:CD8 ratio in OSMF tissues show the activation of cellular immune response which results in deranged immunoregulation and an altered local tissue morphology. These changes may be due to direct stimulation from exogenous antigens such as areca alkaloids or due to changes in tissue antigenicity leading to an autoimmune response. $^{15}$

Increased levels of pro-inflammatory cytokines and reduced antifibrotic interferon gamma (IFNgamma) also contribute to the pathogenesis of OSMF.

Various staging/grading classification systems have been documented in medical literature by various authors in the past. Some of the staging system is routinely used in the clinical practice and help in early diagnosis and treatment. ${ }^{16}$

\section{CLASSIIFICATION BASEID ON CLINICAL FEATURES}

1) Pindborg $\mathbf{J J}^{17}$ (1989) divided OSMF into three stages:

Stage 1: Stomatitis includes erythematous mucosa, vesicles, mucosal ulcers, melanotic mucosal pigmentation and mucosal petechiae.

Stage 2: Fibrosis occurs in healing vesicles and ulcers, which is the hallmark of this stage.

Stage 3: Sequelae of OSMF are as follows:

- Involvement of one-third or less of the oral cavity (if three or less of the above sites are involved).

- Involvement of one to two-thirds of the oral cavity (if four to six intraoral sited are involved).

- Involvement of more than two-thirds of the oral cavity (if more than six intraoral sites are involved).

2) Haider et al ${ }^{18}$ (2011) study based on severity of the disease with functional staging and objective measures inter-incisal opening:

\section{Clinical Staging:}

Stage 1: Facial bands only

Stage 2: Facial and buccal bands 
Stage 3: Facial and labial bands

\section{Functional Stage:}

Stage A: Mouth opening 13 to $20 \mathrm{~mm}$

Stage B: Mouth opening 10 to $11 \mathrm{~mm}$

Stage C: Mouth opening <10mm

\section{CLASSIFICATION BASED ON HISTO - PATHOLOGIC FEATURES}

3) Utsonumiya $\mathbf{H}$ et al $^{18}$ (2005) divided OSMF based on the concept of Pindborg J.J. and Sirsat

S.M. and modified it as follows:

Early stage: Large number of lymphocytes in the sub epithelial and connective tissue zones along with myxedematous changes.

Intermediate stage: Granulation changes close to the muscle layer and hyalinization appears in sub epithelial zone where blood vessels are compressed by fibrous bundles. Reduced inflammatory cells in sub epithelial layer are seen.

Advanced stage: Inflammatory cell infiltrate hardly seen. Number of blood vessels dramatically less in the sub epithelial zone. Marked fibrous areas with hyaline changes extending from sub epithelial to superficial muscle layers are seen. Atrophic, degenerative changes start in muscle fibres.

\section{CLASSIFICATION BASED ON RADIOLOGIC} FEATURES

4) Prakash $\mathbf{R}$ et al $^{19}$ (2014) assessed the morphologic variants of soft palate by conducting a clinico-radiological study. The authors based on these variants assessed the severity of OSMF to establish it as a basis for staging of OSMF.

Six morphologic variants were delineated as follows (Figure 1):

Type 1: Leaf shaped

Type 2: Rat tail shaped
Type 3: Butt shaped

Type 4: Straight line

Type 5: Deformed S

Type 6: Crook shaped

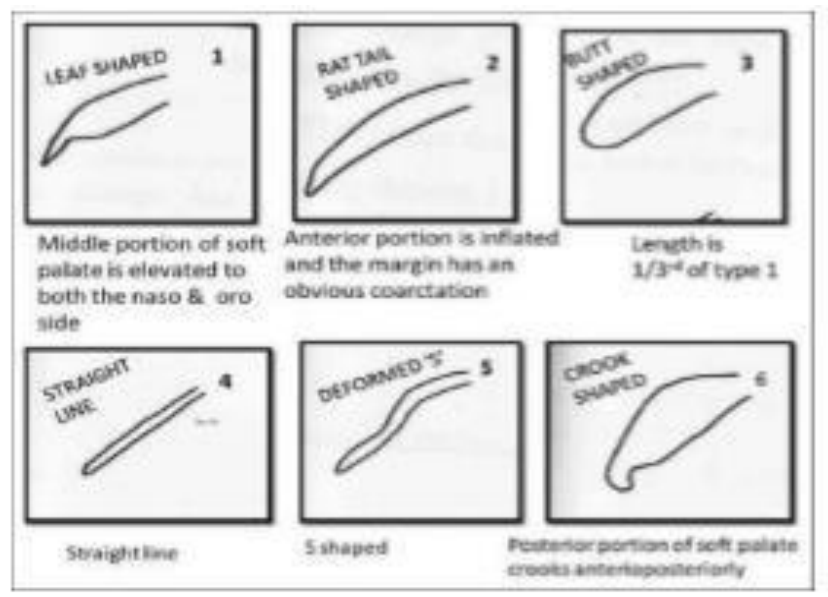

Figure 1: Diagrammatic representation of various shapes of soft palate.

Although these classifications are helpful in clinical diagnosis of patient into different categories but these classification have not highlighted, treatment, and prognosis of the disease. ${ }^{20}$

\section{5) Passi D et al classification (2017) ${ }^{20}$}

Passi D et al. (2017) have proposed a new classification which incorporates treatment and prognosis of OSMF.

The newer classification system includes all the parameters/ component of OSMF such as clinical features, histopathological features, functional component, treatment part, and prognosis.

None of the previous classifications have included all these features in one classification. The main drawback of this classification is that it is bit complex and lengthy. ${ }^{20}$

As per new classification system following treatment options are available which can be given alone or in combination to the patient. 


\section{CLASSIFICATION OF ORAL SUBMUCOUS FIBROSIS: PASSI D ET AL.}

\begin{tabular}{|c|c|c|c|c|c|}
\hline $\begin{array}{l}\text { Grading/ } \\
\text { staging }\end{array}$ & Clinical & Functional & Histopathological & Treatment & Prognosis \\
\hline Grade 1 & $\begin{array}{l}\text { Involvement of less } \\
\text { than one-third of the } \\
\text { oral cavity Mild } \\
\text { blanching, burning } \\
\text { sensation, recurrent } \\
\text { ulceration, stomatitis } \\
\text { and dryness of } \\
\text { mouth }\end{array}$ & $\begin{array}{l}\text { Mouth opening } \\
\text { up to } 35 \mathrm{~mm}\end{array}$ & $\begin{array}{l}\text { Stage of } \\
\text { inflammation: Fine } \\
\text { edematous collagen, } \\
\text { congested blood } \\
\text { vessels, abundant } \\
\text { neutrophils along with } \\
\text { lymphocytes with } \\
\text { myxomatous changes } \\
\text { in subepithelial, } \\
\text { connective tissue layer } \\
\text { of epithelium }\end{array}$ & $\begin{array}{l}\text { Cessation of } \\
\text { habit, nutritional } \\
\text { supplement, } \\
\text { antioxidants, } \\
\text { topical steroid } \\
\text { ointment }\end{array}$ & Excellent \\
\hline Grade 2 & $\begin{array}{l}\text { Involvement of one- } \\
\text { third to two-third of } \\
\text { the oral cavity. } \\
\text { Blanching of oral } \\
\text { mucosa with mottled } \\
\text { and marble like } \\
\text { appearance, fibrotic } \\
\text { bands palpable and } \\
\text { involvement of soft } \\
\text { palate and premolar } \\
\text { area }\end{array}$ & $\begin{array}{l}\text { Mouth opening } \\
25-35 \mathrm{~mm} \\
\text { Cheek } \\
\text { flexibility } \\
\text { reduced by } \\
33 \%\end{array}$ & $\begin{array}{l}\text { Stage of hyalinization: } \\
\text { Juxta-epithelial } \\
\text { collagen hyalinization } \\
\text { with lymphocytes, } \\
\text { eosinophils. Dilated } \\
\text { and congested blood } \\
\text { vessels. Less } \\
\text { fibroblastic activity. } \\
\text { Granulation changes } \\
\text { in muscle layer with } \\
\text { reduced inflammatory } \\
\text { cells in subepithelial } \\
\text { layer }\end{array}$ & $\begin{array}{l}\text { Habit cessation, } \\
\text { nutritional } \\
\text { supplement, } \\
\text { intralesional } \\
\text { injection of } \\
\text { placental } \\
\text { extracts, } \\
\text { Hyaluronidase, } \\
\text { Steroid therapy, } \\
\text { Physiotherapy }\end{array}$ & $\begin{array}{l}\text { Good. } \\
\text { Recurrence } \\
\text { rate is low }\end{array}$ \\
\hline Grade 3 & $\begin{array}{l}\text { Involvement of } \\
\text { greater than two- } \\
\text { third of the oral } \\
\text { cavity. Severe } \\
\text { blanching, Broad } \\
\text { thick fibrous } \\
\text { palpable bands at } \\
\text { cheeks and lips and } \\
\text { rigid mucosa, } \\
\text { depapillated tongue } \\
\text { and restricted tongue } \\
\text { movement and } \\
\text { shrunken bud like } \\
\text { uvula. Floor of the } \\
\text { mouth involvement } \\
\text { and } \\
\text { lymphadenopathy. }\end{array}$ & $\begin{array}{l}\text { Mouth opening } \\
15-25 \mathrm{~mm} \\
\text { Cheek } \\
\text { flexibility } \\
\text { reduced by } \\
66 \%\end{array}$ & $\begin{array}{l}\text { Stage of fibrosis: } \\
\text { Complete collagen } \\
\text { hyalinization without } \\
\text { fibroblast and edema. } \\
\text { Obliterated blood } \\
\text { vessels, Plasma cells } \\
\text { and lymphocytes are } \\
\text { present. Extensive } \\
\text { fibrosis with } \\
\text { hyalinization from } \\
\text { subepithelial to } \\
\text { superficial muscle } \\
\text { layers with atrophic, } \\
\text { degenerative changes }\end{array}$ & $\begin{array}{l}\text { Surgical } \\
\text { treatment } \\
\text { including band } \\
\text { excision and } \\
\text { reconstruction } \\
\text { with BFP or } \\
\text { split thickness } \\
\text { graft bilateral } \\
\text { temporalis } \\
\text { myotomy and } \\
\text { coronoidectomy }\end{array}$ & $\begin{array}{l}\text { Fair. } \\
\text { Recurrence } \\
\text { rate is high }\end{array}$ \\
\hline
\end{tabular}


CLASSIFICATION OF ORAL SUBMUCOUS FIBROSIS: PASSI D ET AL.

\begin{tabular}{|c|l|l|l|l|l|}
\hline $\begin{array}{c}\text { Grading/ } \\
\text { staging }\end{array}$ & \multicolumn{1}{|c|}{ Clinical } & Functional & Histopathological & Treatment & Prognosis \\
\hline Grade 4 & $\begin{array}{l}\text { Leukoplakia } \\
\text { changes, } \\
\text { erythroplakia } \\
\begin{array}{l}\text { Ulcerating and } \\
\text { suspicious } \\
\text { malignant } \\
\text { lesion }\end{array}\end{array}$ & $\begin{array}{l}\text { Mouth } \\
\text { opening <15 } \\
\text { mm or nil }\end{array}$ & $\begin{array}{l}\text { Stages of malignant } \\
\text { transformation: } \\
\text { Erythroplakia } \\
\text { changes into } \\
\text { squamous cell } \\
\text { carcinoma }\end{array}$ & $\begin{array}{l}\text { Surgical } \\
\text { treatment and } \\
\text { biopsy of } \\
\text { suspicious } \\
\text { lesion }\end{array}$ & $\begin{array}{l}\text { Poor, malignant } \\
\text { transformation }\end{array}$ \\
& & & & \\
\hline
\end{tabular}

\section{MANAGEMENT OF OSMF}

\section{Cessation of habit}

The stoppage of habit such as betel quid, areca nut and other local irritants, spicy and hot food, alcohol, and smoking through education and patient motivation. All affected patients should be educated and warned about the possible malignant transformation. $^{20}$

\section{Supplementary care}

Diet rich in iron, vitamins, and minerals should be advised to patients with OSMF. Deficiency of iron plays important role in both etiology and pathogenesis of OSMF. Vitamin B complex supplements may relieve glossitis, inflammation of tongue, and cheilosis in OSMF patients. ${ }^{21}$

\section{Antioxidants}

Carotenoids (lycopene) induce stimulation of immune system or direct action in tumor cells. Lycopene inhibits hepatic fibrosis genes in LEC rats and also exerts a similar inhibition on the abnormal fibroblasts in $\mathrm{OSMF}^{22}$.

\section{Steroid therapy}

Steroids $\rightarrow$ reduction of proliferation of fibroblasts $\rightarrow$ number of collagen fibers decreases. Steroids release cellular proteases enzymes in extracellular compartment in connective tissues $\rightarrow$ activation of collagen and zymogens $\rightarrow$ ingestion of insoluble collagen $\rightarrow$ collagen breakdown stimulation. ${ }^{23}$

\section{Hyaluronidase}

It acts by breaking down hyaluronic acid, lowers the viscosity of intracellular substances, and decreases collagen formation. It produces burning sensation and trismus. Combination of steroids and Hyaluronidase shows better long-term results than either used alone. $^{24}$

\section{Pentoxifylline}

Pentoxifylline is a tri substituted methyl methylxanithine derivative. It is a rheological modifier; it improves microcirculation and decreased platelet aggregation as well as granulocyte adhesion and also has good improvement in radiation-induced superficial fibrotic lesions of skin and direct effect on inhibiting burn scar fibroblasts. It has also been used to alleviate the symptoms in patients with OSMF. $^{25}$

\section{Interferon-gamma}

It has immuno-regulatory effect. It is also known as antifibrotic cytokine, patients treated with an intralesional injection of IFN-gamma experienced improvement of symptoms. ${ }^{26}$ 


\section{Immune milk}

Immune milk consists of anti-inflammatory component which suppresses the inflammatory process and stimulates the cytokine production. Good symptomatic relief in OSMF patients is due to micronutrients in the immune milk powder. ${ }^{27}$

\section{Diathermy, Ultrasound, Lasers: Microwave diathermy}

Microwave diathermy acts by physio-fibrinolysis of fibrous bands through selective heating of juxtaepithelial connective tissue. Ultrasound has a role in deep heating modality. Its selectivity raises the temperature in accumulated areas. $\mathrm{CO} 2$ laser techniques involve multiple small incisions which provide surgical relief of restricted oral aperture because the laser beam seals all the blood vessels, thus allowing the surgeon a perfect visibility and accuracy in fibrous band excision. ${ }^{28}$

\section{Cryosurgery}

It is the method of locally destroying the abnormal tissue by freezing it in situ and applying liquid nitrogen or argon gas. ${ }^{29}$

\section{Surgical treatment}

In patients with severe trismus, surgical intervention is done which includes simple excision of fibrotic bands with reconstruction using buccal fat pad and split thickness graft along with temporalis myotomy and coronoidectomy. The surgery is performed under general anesthesia. The intubation is difficult due to restricted mouth opening. Endotracheal intubation under deep inhalational anesthesia or using muscle relaxants with regional block is preferred. Fiber-optic guided intubation techniques have also been used. ${ }^{20}$

\section{CONCLUSION}

In OSMF, the initial diagnosis is of utmost importance, as the treatment and its prognosis greatly depend on its staging. An attempt is made to update the knowledge on classification schemes for
OSMF so as to assist in categorisation of this premalignant condition and to aid in early diagnosis thereby leading to timely management. An increased emphasis is placed on clinical staging as clinical appearance holds the most important value in staging OSMF. Treatment if done according to the staging and grading helps in management \& better prognosis for the patient. Hence treatment should be done as per the staging and grading. We hope this review helps academicians, clinicians as well as researchers in getting a broad view on various classification systems and contribute to optimal patient management. ${ }^{20}$

Financial support and sponsorship: Nil.

Conflicts of interest: There are no conflicts of interest

\section{REFERENCES}

1) Akbar M. Oral submucous fibrosis - a clinical study. J Indian Dent Acad 1976; 48: 365-73.

2) Shevale V.V., Rinku D.K., Vruturaj V.S., Milind D.S. Management of Oral submucous fibrosis. A review. Ind J. Dent Sci. 2012; 2: 107-14.

3) Schwartz J. Atrophiaidiopathica (tropica) mucosa oris. Demonstrated at the 11th International Dental Congress, London 1952.

4) Joshi S.G: Submucous fibrosis of the palate and pillars. Indian J. Otolaryngol 1953; 4:1-4.

5) Arakeri G., Brennan P.A. Oral submucous fibrosis. An overview of the etiology, pathogenesis, classification and principles of management. $\mathrm{Br} \mathrm{J}$. Oral MaxillofacSurg2013; 51: 587-93.

6) Angadi P.V., Rao S. Management of oral submucous fibrosis: An overview. J. Oral MaxillofacSurg2010; 14:133-42.

7) Warnakulasuriya K.A., Trivedy C., Maher R., Johnson N.W. Aetiology of oral submucous fibrosis. Oral Dis 1997; 3:286-87. 
8) Sinor P.N., Gupta P.C., Murti P.R. et al. A case control study of oral submucous fibrosis with special reference to the etiologic role of areca nut. $\mathbf{J}$ Oral Pathol Med 1990; 19:94-98.

9) Tilakaratne WM, Klinikowski MF, Saku T, Peters TJ, Warnakulasuriya S. Oral submucous fibrosis: Review on aetiology and pathogenesis. Oral Oncol 2006;42:561-8.

10) Chang YC, Tai KW, Lu CK, Chou LS, Cahi MY. Cytopathic effects of arecoline on human gingival fibroblasts in vitro. Clin Oral Invest 1999;3:25-9.

11) Meghji S, Scutt A, Harvey W, Canniff JP. An in vitro comparison of human fibroblasts from normal and oral submucous fibrosis tissue. Arch Oral Biol 1987;32:213-5.

12) Trivedy $C$, Baldwin $D$, Warnakalsuriya $S$, Johnson NW, Peters JJ. Copper content in Areca catechu (betel nut) products and OSMF. Lancet 1997;349:1447.

13) Trivedy C, Warnakulasuriya KA, Peters TJ, Senkus R, Hazarey VK, Johnson NW. Raised tissue copper levels in oral submucous fibrosis. J Oral Pathol Med 2000:29:241-8.

14) Rajendran R, Deepthi K, Nooh N, Anil S. A4ß1 integrin dependent cell sorting cell recruitment in oral submucous fibrosis.J Oral Maxillofacal Pathol2011;15:272-7.

15) Haque MF, Harris M,Meghji S, Speight PM. An immunohistochemical study of oral submucous fibrosis. J Oral Pathol Med 1997;26:75-82.

16) Haque MF, Meghji S, Khitab U, Harris M. Oral submucous fibrosispatients have altered levels of cytokine production. J Oral Pathol Med 2000;29:123-8.

17) Ranganathan K, Gauri Mishra. An overview of classification schemes of OSMF. Journal of Oral And Maxillofacial Pathology, 2006 Jul-Dec; 10(2); 55-58.
18) Haider S M ,Merchant AT, Pikra FF, Rahbar MH: Clinical and functional staging of OSMF. Br. Journal Of Oral And Maxillofacial Surgery 38,1215.

19) Prakash R., Mohan S., Verma S., Singh U., Agarwal N. Morphometric evaluation of soft palate in oral submucous fibrosis: A digital cephalometric analysis. West Afr J. Radiol 2014; 21: 7-11.

20) Passi D, Bhanot $P$, Kacker D, Chahal D, Atri M, Panwar Y. Oral submucous fibrosis: Newer proposed classification with critical updates in pathogenesis and management strategies. National Journal of maxillofacial surgery, 2017 Jul;8(2):8994.

21) Martin H, Koop EC. Precancerous mouth lesions of vitaminosis $\mathrm{B}$; their etiology, response to therapy and relationship to oral cancer. Am J Surg1942;57:195.

22) Kumar A, Bagewad I A, Keluskar V, Singh M. Efficacy of lycopene in the management of oral submucous fibrosis. Oral Surg Oral Med Oral Pathol Oral Radiol Endod 007;103:207-13.

23) Lavina T, Anjana B, Vaishali K. Haemoglobin levels in patients with oral submucous fibrosis. JIAOMR 2007;19:329-33.

24) Kakar PK, Puri RK, Venkatachalam VP. Oral submucous fibrosistreatment with hyalase. J Laryngol Otol 1985;99:57-9.

25) Rajendran R, Rani V, Shaikh S. Pentoxifylline therapy: A new adjunct in the treatment of oral submucous fibrosis. Indian J Dent Res 2006;17:190198.

26) Haque MF, Meghji S, Nazir R, Harris $M$. Interferon gamma (IFN- gamma) may reverse oralsubmucous fibrosis. J Oral Pathol Med 2001;30:12-21.

27) Tai YS, Liu BY, Wang JT, Sun A, Kwan HW, Chiang CP. Oral administration of milk from cows immunised with human intestinal bacteria leads to 
significant improvements symptoms and signs in patients with oral sub mucous fibrosis. J Oral Pathol Med 2001;30:618-25.

28) Bierman W. Ultrasound in the treatment of scars. Arch Phys Med Rehabil 1954;35:209-14.

29) Frame JW.Carbondioxide laser surgery for benign oral lesions. Br Dent J 1985;158:125-8. 